\title{
Pharmacokinetics of human chorionic gonadotropin after i.m. administration in goats (Capra hircus)
}

\author{
M Saleh, M Shahin, W Wuttke ${ }^{1}$, M Gauly and W Holtz \\ Department of Animal Science, Georg-August-University, Albrecht-Thaer-Weg 3, 37075 Goettingen, Germany and \\ ${ }^{1}$ Division of Endocrinology, University Medical Centre, 37075 Goettingen, Germany \\ Correspondence should be addressed to W Holtz; Email: wholtz@gwdg.de
}

\begin{abstract}
The present investigation addresses the pharmacokinetics of human chorionic gonadotropin (hCG), intramuscularly (i.m.) administered to goats. Nine pluriparous does of the Boer goat breed, 2-6 years of age and weighing 45-60 kg, were administered 500 IU hCG (2 ml Chorulon) deep into the thigh musculature $18 \mathrm{~h}$ after superovulatory FSH treatment. Blood samples were drawn from the jugular vein at $2 \mathrm{~h}$ intervals for the first $24 \mathrm{~h}$, at $6 \mathrm{~h}$ intervals until $42 \mathrm{~h}$, and at $12 \mathrm{~h}$ intervals until $114 \mathrm{~h}$ after administration. After centrifugation, plasma hCG concentrations were determined by electrochemiluminescence immunoassay. Pharmacokinetical parameters were as follows: lag time, 0.4 (s.E.M. 0.1) h; absorption rate constant, 0.34 (s.E.M. 0.002) h; absorption half-life, 2.7 (s.E.M. 0.5) h; elimination rate constant, 0.02 (S.E.M. 0.002) h; biological half-life, 39.4 (s.E.M. 5.1) h; and apparent volume of distribution, 16.9 (s.E.M. 4.3) I. The plasma hCG profile was characterized by an absorption phase of $\mathbf{1 1 . 6}$ (S.E.M. 1.8) $\mathbf{h}$ and an elimination phase of 70.0 (S.E.M. 9.8) $\mathrm{h}$, with considerable individual variation in bioavailability and pharmacokinetical parameters. Biological half-life was negatively correlated $(P<0.05)$ with peak concentration $(r=-0.76)$, absorption rate constant $(r=-0.78)$, and elimination rate constant $(r=-0.87)$. The results indicate that after rapid absorption, hCG remains in the circulation for an extended period. This has to be taken into account when assessing the stimulatory response to hCG treatment on an ovarian level.
\end{abstract}

Reproduction (2012) 144 77-81

\section{Introduction}

Human chorionic gonadotropin ( $\mathrm{hCG}$ ) is a heterodimeric glycoprotein of $57 \mathrm{kDa}$ consisting of a noncovalently bound $\alpha$-subunit (92 amino acids) and a distinctive $\beta$-subunit (134 amino acids). It has the $\alpha$-subunit in common with the glycoprotein hormones $\mathrm{LH}, \mathrm{FSH}$, and $\mathrm{TSH}$. The $\beta$-subunit is unique for each of these hormones and responsible for their specific functions (Gupta \& Dighe 2000, Senger 2005, De Rensis et al. 2010). The $\beta$-hCG chain shows $80 \%$ homology with the 121 amino acid subunit of the LH $\beta$-subunit (Norman \& Litwack 1997). The prime source of hCG is the trophoblast of the human embryo and, after implantation, the villous syncytiotrophoblast of the placenta (Cole 2010). hCG contributes to maternal recognition of the developing human embryo at about 6-8 weeks of pregnancy (Senger 2005, Cole 2010). Furthermore, it initiates angiogenesis via growth factors to prepare the uterus for implantation (Zygmunt et al. 2002, Filicori et al. 2005, Cole 2010) and induces the initial production of progesterone by the corpus luteum until the placenta synthesizes adequate amounts to maintain gravidity (Norman \& Litwack 1997).

Due to the structural similarity of hCG with $\mathrm{LH}$, it exerts an effect by binding to LH receptors (Lei \& Rao
1994, Birken et al. 1996). The prolonged activity and low clearance rate of hCG, in comparison to endogenous $\mathrm{LH}$, are a consequence of the high glycosylation rate (Cole 2010). More than $75 \%$ of the hCG molecules are degraded in the liver; the remaining molecules are eliminated via the kidney (Cole 2010). hCG for clinical purposes is extracted from urine of pregnant women (Farrag et al. 2008). Alternatively, hCG may be derived via recombinant DNA technology from genetically engineered Chinese hamster ovary cells (Farrag et al. 2008).

In humans, hCG is extensively used as an ovulationinducing agent in lieu of LH (Nader \& Berkowitz 1990) and, after introduction of IVF and ICSI, in in vitro maturation of oocytes (Farrag et al. 2008). In men, hCG is used to stimulate the Leydig cells to synthesize testosterone to support spermatogenesis (Heller \& Leach 1971). In domestic animals, hCG has a wide range of applications. It is used in the context of estrus synchronization in cattle and horses (Schmitt et al. 1996, Ginther et al. 2009) and ovulation induction in sheep and goats (Wani et al. 1997, Saleh et al. in preparation) as well as in fish (Kahkesh et al. 2010), to overcome the negative effect of premature regression of corpora lutea after superovulatory treatment in goats (Saharrea et al. 1998), and for improving pregnancy rate in cattle 
and goats (Rajamahendran \& Sianangama 1992, Fonseca \& Torres 2005). There is a paucity of information on the pharmacokinetics of hCG in domestic animals with the exception of cats (Swanson et al. 1997). The objective of this study was to characterize the pharmacokinetics of hCG following an i.m. injection to induce ovulation in superovulated Boer goat does.

\section{Results}

The plasma profile arising from the hCG injection is depicted in Fig. 1. Individual variation is reflected by the dimension of the range (shaded area) and S.D.. Parameters characterizing the profile are presented in Table 1. Observed and calculated peak concentrations $\left(C_{\text {peak }}\right)$ of 64.6 and $70.9 \mathrm{mIU} / \mathrm{ml}$ were arrived after 11.6 and $11.0 \mathrm{~h}$, respectively, with substantial individual variation ranging from 40 to $85 \mathrm{mlU} / \mathrm{ml}$ for observed and 50 to $99 \mathrm{mIU} / \mathrm{ml}$ for calculated peak concentrations. Individual differences in pattern and amplitude of plasma hCG concentration are also reflected by the formidable range in area under the curve (1632$3118 \mathrm{~h} \mathrm{mIU} / \mathrm{ml}$ ). The pharmacokinetic parameters are presented in Table 2. Absorption from the site of administration was rapid, as indicated by the lag time $\left(T_{0}\right)$ of $0.4 \mathrm{~h}$ and the absorption half-life $\left(T_{0.5 \mathrm{abs}}\right)$ of $2.7 \mathrm{~h}$. The mean absorption rate constant $\left(K_{\mathrm{a}}\right)$ was 0.34 and the biological half-life $\left(T_{0.5 \mathrm{elm}}\right)$ was $39.4 \mathrm{~h}$. Both absorption and elimination of hCG took place in an almost linear fashion (Fig. 2). However, whereas absorption took place rapidly, the elimination phase was characterized by a gradual decline extending to, on the average, 70 (s.E.M. 9.8, range 30-106) h (Table 1); traces of hCG were found in the system after 5 days.

The correlation between absorption rate constant and elimination half-life was $r=-0.78(P=0.01)$. Pearson's correlation coefficients between peak concentration on the one hand and half-life $(r=-0.76, P=0.02)$,

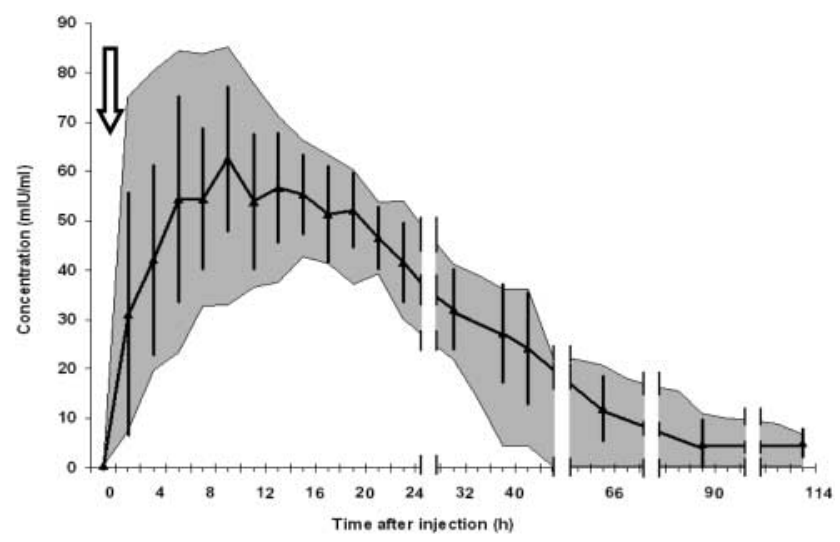

Figure $1 \mathrm{hCG}$ concentrations recorded after single i.m. administration of $500 \mathrm{IU}$ hCG (arrow) (mean, s.D., minimum and maximum) to nine adult Boer goat does.
Table 1 Characterization of plasma hCG profile (observed and calculated time of maximum concentration: $T_{\text {peak; }}$ observed and calculated peak plasma concentration: $C_{\text {peak }}$; duration of absorption and elimination phases; and the area under the curve: $\mathrm{AUC}$ ) after i.m. administration of 500 IU hCG in nine adult Boer goat does.

\begin{tabular}{lccc}
\hline Parameter & Mean & S.E.M. & Range \\
\hline$T_{\text {peak }}(\mathrm{h})$ & & & \\
Observed & 11.6 & 1.8 & $4-20$ \\
Calculated & 11.0 & 1.9 & $5-20$ \\
$C_{\text {peak }}(\mathrm{mlU} / \mathrm{ml})$ & & & \\
Observed & 64.6 & 4.9 & $40-85$ \\
$\quad$ Calculated & 70.9 & 4.6 & $50-99$ \\
Duration $(\mathrm{h})$ of & & & \\
Absorption phase & 11.6 & 1.8 & $4-20$ \\
$\quad$ Elimination phase & 70 & 9.8 & $30-106$ \\
AUC (h mlU/ml) & 2427 & 177 & $1632-3118$ \\
\hline
\end{tabular}

elimination rate constants $(r=0.67, P=0.05)$, and apparent volume of distribution $(r=-0.97, P=0.0001)$ on the other hand were significant; however, clearance rate was not related $(r=0.06, P=0.90)$.

\section{Discussion}

This study addresses the pharmacokinetics of intramuscularly injected hCG in goats. The plasma hCG profile following injection was characterized by rapid absorption $(11.6 \mathrm{~h})$ and slow elimination $(70.0 \mathrm{~h})$ with substantial individual variation in bioavailability.

Fitting the plasma hCG profile to the most appropriate model revealed that hCG follows a two-compartment pharmacokinetic model (Jambhekar \& Breen 2009). The pattern of essentially linear absorption and elimination phases resembles that of humans (Weissman et al. 1996, Chan et al. 2003) and domestic cats (Swanson et al. 1997).

The substantial individual variation in peak levels might be associated with individual differences in the hypothetical volume of distribution which ranged from 12-25 I. The more hCG molecules are bound to target tissue, the lower the plasma concentration is expected to be. Hence, this is an indication of the hypothetical volume into which hCG is distributed. The biological half-life of, on average, $39.4 \mathrm{~h}$ is in close agreement with the $36 \mathrm{~h}$ reported for humans (Cole 2010) but longer than the $26.1 \mathrm{~h}$ observed in domestic cats (Swanson et al. 1997).

The negative correlation between absorption rate constant and elimination half-life suggests that, if absorption of hCG is rapid, so will be clearance from the circulation. In does with low peak concentrations, half-life was longer; accordingly, elimination rate was lower and apparent volume of distribution was higher. The clearance rate was unaffected.

Elimination from the circulation follows the pattern typical for a two-compartment model (Jambhekar \& Breen 2009). The average duration of the elimination phase of $70 \mathrm{~h}$ reflects the time hCG molecules reside in the circulation. The elimination phase of hCG, being 
Table 2 Pharmacokinetic parameters: lag time $\left(T_{0}\right)$, absorption rate constant $\left(K_{\mathrm{a}}\right)$, absorption half-life $\left(T_{0.5 \mathrm{abs}}\right)$, elimination rate constant $\left(K_{\mathrm{e}}\right)$, elimination (biological) half-life $\left(T_{0.5 \mathrm{elm}}\right)$, apparent volume of distribution $\left(V_{\mathrm{d}}\right)$, and clearance rate after i.m. administration of $500 \mathrm{IU}$ hCG in nine adult Boer goat does.

\begin{tabular}{lclc}
\hline Parameter & Mean & s.E.M. & Range \\
\hline$T_{0}(\mathrm{~h})$ & 0.40 & 0.06 & $0.33-0.66$ \\
$K_{\mathrm{a}}($ per $\mathrm{h})$ & 0.34 & 0.06 & $0.13-0.62$ \\
$T_{0.5 \mathrm{abs}}(\mathrm{h})$ & 2.70 & 0.54 & $1.1-5.3$ \\
$K_{\mathrm{e}}($ per $\mathrm{h})$ & 0.02 & 0.002 & $0.01-0.03$ \\
$T_{0.5 \mathrm{elm}}(\mathrm{h})$ & 39.4 & 5.1 & $25-66$ \\
$V_{\mathrm{d}}(\mathrm{l})$ & 16.9 & 4.3 & $12-25$ \\
Clearance rate $(\mathrm{l} / \mathrm{h})$ & 0.2 & 0.02 & $0.2-0.3$ \\
\hline
\end{tabular}

about seven times as long as the absorption phase, reflects the extremely slow clearance process especially when contrasted with a clearance rate of $1.9 \mathrm{l} / \mathrm{h}$ for endogenous LH released during the preovulatory surge recorded in the same group of goats (Saleh et al. in preparation). Compared with humans (Weissman et al. 1996) and domestic cats (Swanson et al. 1997), the retention time of hCG in the circulation of goats falls within an intermediate range. According to Schmitt et al. (1996), the increase in plasma concentration in hCGinjected cows lasted for $30 \mathrm{~h}$, which is much shorter than in goats. The slow rate of degradation is said to be due to sialic acid residuals on the $\beta$-subunit of the hCG molecule (Kalyan et al. 1982, Nisula et al. 1989, Kobata 2010). In humans, it has been shown that these residuals are enzymatically dissociated (Apparailly \& Combarnous 1994, Zygmunt et al. 2002, Chan et al. 2003), followed by the binding of the molecule to hepatic receptors and degradation. This pathway takes care of more than three quarters of the biologically active hCG; the remaining is cleared via the kidney. Approximately, $21 \%$ is excreted via the urine as heterodimeric hCG, nicked heterodimeric hCG, free subunits (some nicked), and, predominantly, hCG $\beta$ core fragment (Cole 2010). Elimination rates via liver and kidney might differ depending on the physiological state (Rao 1985), interactions with other hormones or substances (Liu et al. 1995), route of administration (Saal et al. 1991, Wikland et al. 1995, Stelling et al. 2003), body mass index (Chan et al. 2003, Detti et al. 2007), and the presence of large ovarian follicles (Detti et al. 2007).

In the present experiment, ultrasound monitoring of the ovaries revealed that ovulation occurred $\sim 34 \mathrm{~h}$ after hCG treatment. Taking this into consideration, it may be surmized that the prolonged bioavailability of hCG, lasting until well after ovulation, might possibly be supportive of corpus luteum function, but might, on the other hand, also be responsible for interference with postovulatory ovarian function. A study, involving possible functional aspects of hCG, including possible interaction with $\mathrm{LH}$ and direct or indirect effect on ovulation, is about to be completed and will be published in due course.
In conclusion, hCG injected i.m. to goats will rapidly make its appearance in the circulation, whereas clearance from the blood occurs gradually lasting, on average, for $70 \mathrm{~h}$. There is considerable individual variability in time course and amplitude of these events.

\section{Materials and Methods Animals}

The experiment was conducted on pluriparous Boer goat does, 2-6 years of age and weighing $45-60 \mathrm{~kg}$, from the departmental breeding flock at Goettingen, Germany $\left(9^{\circ} 41^{\prime} \mathrm{E}, 51^{\circ}\right.$ $46^{\prime} \mathrm{N}$ ) during the breeding season (October to January). The does were group-housed in open barns with straw-bedding and outdoor concrete runs. They were fed a daily ration of $600 \mathrm{~g}$ concentrate, consisting of equal parts of a pelleted diet for breeding ewes (16\% crude protein, $10.2 \mathrm{MJ} \mathrm{ME} / \mathrm{kg}$, supplemented with $43 \mathrm{mg} / \mathrm{kg}$ Se, $12 \mathrm{mg} / \mathrm{kg} \mathrm{l}$, and $5000 \mathrm{mg} / \mathrm{kg}$ $\mathrm{Zn}$ ), oats, and dried sugar beet pulp and had free access to wheat or barley straw, salt lick, and water. Once daily, the does were routinely tested for estrus with an aproned male.

\section{Donor preparation and superovulation}

From 4 days after observed estrus, daily blood samples were drawn from does to be tested for plasma progesterone concentration. Once the concentration exceeded $5 \mathrm{ng} / \mathrm{ml}$, an i.m. injection of $5.0 \mathrm{mg}$ dinoprost $(1 \mathrm{ml}$ Dinolytic; Pfizer, Karlsruhe, Germany) was administered. Seven days later,
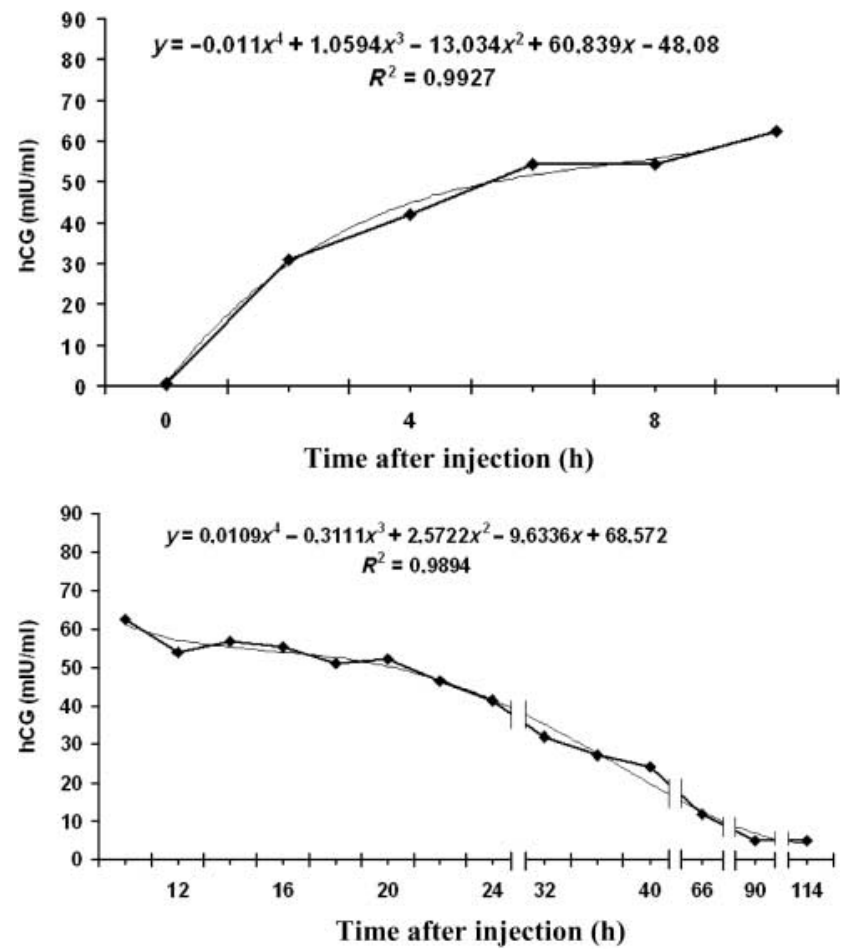

Figure 2 Absorption (top) and elimination phase (bottom) of the plasma hCG profile in the wake of i.m. administration of $500 \mathrm{IU}$ to nine adult Boer goat does (fitted with polynomial trend lines). 
an i.m. injection of $0.004 \mathrm{mg}$ of the $\mathrm{GnRH}$ analog buserelin (1 ml Receptal; Intervet, Unterschleissheim, Germany) was administered followed, 5 days later, by a series of six s.c. injections of 4, 4, 2, 2, 2, and 2 armour units of pFSH supplemented with $40 \%$ pLH (Nowshari et al. 1995), administered at $12 \mathrm{~h}$ intervals. Along with the last two pFSH injections, $1 \mathrm{ml}$ Dinolytic was administered intramuscularly. To determine the time of ovulation, $18 \mathrm{~h}$ after the last dinoprost injection, does were administered an i.m. injection of $500 \mathrm{IU}$ hCG (2 $\mathrm{ml}$ Chorulon; Intervet) into the thigh musculature ( $\mathrm{m}$. biceps femoris and $\mathrm{m}$. semitendineus).

\section{Blood sampling and determination of hCG concentration}

Throughout the experiment, blood samples of $5 \mathrm{ml}$ were drawn daily via jugular venipuncture. Before hCG administration, does were provided with indwelling jugular catheters, so samples could be drawn at $2 \mathrm{~h}$ intervals for the first $24 \mathrm{~h}$ and at $6 \mathrm{~h}$ intervals for the subsequent $18 \mathrm{~h}$. Thereafter, a routine of daily sampling was resumed. Collection tubes contained three drops of $\mathrm{Na}$-citrate to prevent clotting. After centrifugation at $1000 \mathrm{~g}$ for $10 \mathrm{~min}$, plasma samples were stored at $-20{ }^{\circ} \mathrm{C}$ until being analyzed for hCG concentration by Electrochemiluminescence Immunoassay (ECLIA, ELECSYS; Roche) as described elsewhere (Forest et al. 1998). The assay is based on an electrochemiluminescent label (Ruthenium (II) tris (bipyridyl) $)_{3}^{2+} ; \quad \operatorname{Ru}(\text { bpy })_{3}^{2+}$ ), which can undergo multiple oxidation-reduction cycles when immobilized at the surface of an electrode in the presence of a co-reactant included in the assay buffer. The co-reactant tripropylamine (TPA), when oxidized at the electrode, produces a radical cation, which acts as a reducing agent. After the release of a proton, a TPA radical is formed that reacts with the oxidized form of the label to generate $\mathrm{Ru}(\mathrm{bpy})_{3}^{2+}$ in an excited state. After emission of a photon, the label can undergo another cycle and, therefore, generate multiple photons for each labeled molecule. Immobilization of the labeled complex is achieved by magnetic microparticles coated with streptavidin, which bind to biotin, linked, covalently, to reaction antibodies. A magnet immobilizes the bound fraction at the electrode to allow elimination of the unbound label before proceeding to the electrochemiluminescent detection.

\section{Statistical analysis and calculation of biological half-life}

To characterize the pharmacokinetics, the following parameters for hCG were assessed (Jambhekar \& Breen 2009): lag time $T_{0}$ (time from treatment to first detection), absorption rate constant $K_{\mathrm{a}}\left(0.693 / T_{0.5 \mathrm{abs}}\right)$, absorption half-life $T_{0.5 \mathrm{abs}}$ elimination rate constant $K_{\mathrm{e}}\left(0.693 / T_{0.5 \mathrm{elm}}\right)$, elimination halflife $T_{0.5 \mathrm{elm}}$ and the apparent volume of distribution $V_{\mathrm{d}}$. To assess the absorption half-life $T_{0.5 \mathrm{abs}}$ and the biological half-life $T_{0.5 \mathrm{elm}}$, plasma hCG concentrations of individual does were plotted against time. Absorption half-life was determined as the time required from administration to the point when half of the maximum plasma hCG level was reached, and biological halflife was determined as the time from maximum plasma concentration to half of that level. The apparent volume of distribution, the volume to which a given dose of hCG would have to be diluted to have a concentration equal to the concentration detected in blood, was calculated as $V_{\mathrm{d}}=$ dose/ hCG concentration.

To characterize the bioavailability parameters for hCG, observed and calculated peak concentration $C_{\text {peak, }}$ observed and calculated time of peak occurrence $T_{\text {peak, }}$ and the area under the hCG curve $\mathrm{AUC}_{0-114}$ were determined. These parameters were calculated on the basis of individual plasma concentrations, whereas the calculated values for the peak concentration and the time of peak occurrence $T_{\text {peak }}$ were determined by the formulae $T_{\text {peak }}=\left(\ln \left(K_{\mathrm{a}} / K_{\mathrm{e}}\right)\right) /\left(K_{\mathrm{a}}-K_{\mathrm{e}}\right)$ and $C_{\text {peak }}=I \times\left(\mathrm{e}^{-K_{\mathrm{e}} T_{\text {peak }}}-\mathrm{e}^{-K_{\mathrm{a}} T_{\text {peak }}}\right)$, respectively, where $I$ stands for intercept. The intercept was assigned after the individual elimination curves had been a subject to linear regression analysis. The area under the hCG curve $\mathrm{AUC}_{0-114}$ was calculated by means of the linear trapezoidal approximation using $(A \cup C)_{t 1}^{t 2}=((C p 1+C p 2) / 2) \times\left(t_{2}-t_{1}\right)$, where $C p 1$ and $C p 2$ are hCG concentrations at the corresponding times $t_{1}$ and $t_{2}$ respectively. Pearson correlation coefficients were calculated to identify relationships between the pharmacokinetic parameters using the procedure CORR (SAS 9.2, Cary, NC, USA). Mean and standard error were calculated using the MEANS procedure (SAS 9.2).

\section{Declaration of interest}

The authors declare that there is no conflict of interest that could be perceived as prejudicing the impartiality of the research reported.

\section{Funding}

This research did not receive any specific grant from any funding agency in the public, commercial, or not-for-profit sector.

\section{Acknowledgements}

The authors thank Pfizer (Berlin, Germany) for supplying Dinolytic, Intervet/Germany (Unterschleissheim, Germany) for supplying Receptal and Chorulon, and Elisabeth Stuewe and Heidi Brueggemann for valuable technical assistance.

\section{References}

Apparailly F \& Combarnous Y 1994 Role of sialic acid residues in the in vitro superactivity of human choriogonadotropin (hCG) in rat Leydig cells. Biochimica et Biophysica Acta 1224 559-565. (doi:10.1016/01674889(94)90294-1)

Birken S, Kovalevskaya G \& O'Connor J 1996 Metabolism of hCG and hLH to multiple urinary forms. Molecular and Cellular Endocrinology 125 121-131. (doi:10.1016/S0303-7207(96)03942-1)

Chan CCW, Ng EHY, Chan MMY, Tang OS, Lau EYL, Yeung WSBY \& Ho PC 2003 Bioavailability of hCG after intramuscular or subcutaneous injection in obese and non-obese women. Human Reproduction 18 2294-2297. (doi:10.1093/humrep/deg446)

Cole LA 2010 Degradation products of hCG, hyperglycosylated hCG, and free $\beta$-subunit. In Human Chorionic Gonadotropin (hCG), pp 109-119. Eds LA Cole \& SA Butler. Elsevier, Inc. 
De Rensis F, Lopez-Gatius F, Garcia-Ispierto I \& Techakumpu M 2010 Clinical use of human chorionic gonadotropin in dairy cows: an update. Theriogenology 73 1001-1008. (doi:10.1016/j.theriogenology.2009.11. 027)

Detti L, Mitwally MFM, Rode A, Yelian FD, Kruger M, Diamond MP \& Puscheck EE 2007 Serum human chorionic gonadotropin level after ovulation triggering is influenced by the patient's body mass index and the number of larger follicles. Fertility and Sterility 88 152-155. (doi:10. 1016/j.fertnstert.2006.11.124)

Farrag A, Costantini A, Manna C \& Grimaldi G 2008 Recombinant HCG for triggering ovulation increases the rate of mature oocytes in women treated for ICSI. Journal of Assisted Reproduction and Genetics 25 461-466. (doi:10.1007/s10815-008-9262-x)

Filicori M, Fazleabas AT, Huhtaniemi I, Licht P, Rao ChV, Tesarik J \& Zygmunt M 2005 Novel concepts of human chorionic gonadotropin: reproductive system interactions and potential in the management of infertility. Fertility and Sterility 84 275-284. (doi:10.1016/j.fertnstert. 2005.02.033)

Fonseca JF \& Torres CAA 2005 Administration of hCG 5 days after breeding and reproductive performance in nulliparous dairy goats. Reproduction in Domestic Animals 40 495-499. (doi:10.1111/j.1439-0531.2005. 00612.x)

Forest JC, Masse J \& Lane A 1998 Evaluation of the analytical performance of the Boehringer Mannheim Elecsys 2010 Immunoanalyzer. Clinical Biochemistry 31 81-88. (doi:10.1016/S0009-9120(98)00002-2)

Ginther OJ, Beg MA, Gastal EL, Gastal MO \& Cooper DA 2009 Treatment with human chorionic gonadotropin (hCG) for ovulation induction is associated with an immediate 17beta-estradiol decrease and a more rapid LH increase in mares. Animal Reproduction Science 114 311-317. (doi:10.1016/j.anireprosci.2008.08.026)

Gupta CS \& Dighe RR 2000 Biological activity of single chain chorionic gonadotropin, hCG $\alpha \beta$, is decreased upon deletion of five carboxyl terminal amino acids of the $\alpha$-subunit without affecting its receptor binding. Journal of Molecular Endocrinology 24 157-164. (doi:10.1677/ jme.0.0240157)

Heller CG \& Leach D 1971 Quantification of Leydig cells and measurement of Leydig-cell size following administration of human chorionic gonadotrophin to normal men. Journal of Reproduction and Fertility 25 185-192. (doi:10.1530/jrf.0.0250185)

Jambhekar SS \& Breen PJ 2009 Basic Pharmacokinitics. Pharmaceutical Press.

Kahkesh FB, Feshalami MY, Amiri F \& Nickpey M 2010 Effect of ovaprim, ovatide, hCG, LHRH-A2, LHRHA2 + CPE and carp pituitary in Benni (Barbus sharpeyi) artificial breeding. Global Veterinaria 5 209-214.

Kalyan NK, Lippes HA \& Bahl OP 1982 Role of carbohydrate in human chorionic gonadotropin: effect of periodate oxidation and reduction on its in vitro and in vivo biological properties. Journal of Biological Chemistry 257 12624-12631.

Kobata A 2010 Glycobiology of hCG. In Human Chorionic Gonadotropin (hCG), pp 83-108. Eds LA Cole \& SA Butler. Elsevier, Inc.

Lei ZM \& Rao CV 1994 Novel presence of luteinizing hormone/human chorionic gonadotropin (hCG) receptors and the down-regulation action of hCG on gonadotropin releasing hormone gene expression in immortalized hypothalamic GT1-7 neurons. Molecular Endocrinology 8 1111-1121. (doi:10.1210/me.8.8.1111)

Liu B, Peng J \& Liu Y 1995 The concept of half-life of hormone. Medical \& Biological Engineering \& Computing 33 822-826. (doi:10.1007/ BF02523014)

Nader S \& Berkowitz AS 1990 Study of the pharmacokinetics of human chorionic gonadotropin and its relation to ovulation. Journal of In Vitro Fertilization and Embryo Transfer 7 114-118. (doi:10.1007/ BF01135585)
Nisula BC, Blithe DL, Akar A, Lefort G \& Wehmann RE 1989 Metabolic fate of human choriogonadotropin. Journal of Steroid Biochemistry 33 733-737. (doi:10.1016/0022-4731(89)90485-8)

Norman AW \& Litwack G 1997 Hormones, 2nd edn. London, UK: Academic Press.

Nowshari MA, Beckers JF \& Holtz W 1995 Superovulation of goats with purified FSH supplemented with defined amounts of pLH. Theriogenology 43 797-802. (doi:10.1016/0093-691X(95)00022-Z)

Rajamahendran R \& Sianangama PC 1992 Effect of human chorionic gonadotropin on dominant follicles in cows: formation of accessory corpora lutea, progesterone production and pregnancy rates. Journal of Reproduction and Fertility 95 577-584. (doi:10.1530/jrf.0.0950577)

Rao AJ 1985 Rate of clearance of immunoreactive hCG from the serum of the pregnant Bonnet Monkey (Macaca radiata). Animal Reproduction Science 9 173-179. (doi:10.1016/0378-4320(85)90021-1)

Saal W, Glowania HJ, Hengst W \& Happ J 1991 Pharmacodynamics and pharmacokinetics after subcutaneous and intramuscular injection of human chorionic gonadotropin. Fertility and Sterility 56 225-229.

Saharrea A, Valencia J, Balcazar A, Meja O, Cerbon JL, Caballero V \& Zarco L 1998 Premature luteal regression in goats superovulated with PMSG: effect of hCG or GnRH administration during the early luteal phase. Theriogenology $\mathbf{5 0}$ 1039-1052. (doi:10.1016/ S0093-691X(98)00206-4)

Schmitt EJP, Diaz T, Drost M \& Thatcher WW 1996 Use of gonadotropin releasing hormone or human chorionic gonadotropin for timed insemination in cattle. Journal of Animal Science 74 1074-1083.

Senger PL 2005 Pathways to pregnancy and parturition. 2nd revised edn. Current Conceptions, Pullman, WA, USA.

Stelling JR, Chapman ET, Frankfurter D, Harris DH, Oskowitz SP \& Reindollar RH 2003 Subcutaneous versus intramuscular administration of human chorionic gonadotropin during an in vitro fertilization cycle. Fertility and Sterility 9 881-885. (doi:10.1016/S0015-0282(02)04918-X)

Swanson WF, Wolfe BA, Brown JL, Martin-Jimenez T, Riviere JE, Roth TL \& Wildt DE 1997 Pharmacokinetics and ovarian-stimulatory effects of equine and human chorionic gonadotropins administered singly and in combination in the domestic cat. Biology of Reproduction 57 295-302. (doi:10.1095/biolreprod57.2.295)

Wani GM, Buchoo BA \& Wani NA 1997 Technical note: use of human gonadotrophin in superovulation of Southdown sheep. Small Ruminant Research 25 93-94. (doi:10.1016/S0921-4488(96)00964-9)

Weissman A, Lurie S, Zalel Y, Goldchmit R \& Shoham Z 1996 Human chorionic gonadotropin: pharmacokinetics of subcutaneous administration. Gynecological Endocrinology 10 273-276. (doi:10.3109/ 09513599609012319)

Wikland M, Borg J, Forsberg AS, Jakobsson AH, Peter Svalander P \& Waldenstrom U 1995 Human chorionic gonadotropin self-administered by the subcutaneous route to induce oocyte maturation in an in-vitro fertilization and embryo transfer programme. Human Reproduction 10 1667-1670.

Zygmunt M, Herr F, Keller-Schoenwetter S, Kunzi-Rapp K, Munstedt K, Rao CV, Lang U \& Preissner KT 2002 Characterization of human chorionic gonadotropin as a novel angiogenic factor. Journal of Clinical Endocrinology and Metabolism 87 5290-5296. (doi:10.1210/jc.2002020642)

Received 13 March 2012

First decision 12 April 2012

Revised manuscript received 13 April 2012

Accepted 9 May 2012 